\title{
Who changes the course of history? Historical agency in the narratives of Spanish pre-service primary teachers
}

\author{
Laura Arias-Ferrer* and Alejandro Egea-Vivancos - University of Murcia, Spain
}

\begin{abstract}
Brief narratives created by pre-service teachers on a primary education degree course at the University of Murcia (Spain) were analysed to identify the ways in which they presented historical agents in European and Spanish history. The main units of analysis were categorized by the type of agent introduced in each narrative (individual, collective and institutional), then by identifying agents as either active or passive, and finally by describing the characteristics of their actions in terms of reasons and causes/consequences. The results reveal an emphasis on individual agents and the persistence of a superficial historical master narrative that perpetuates a distorted image of history.
\end{abstract}

Keywords: Spain; historical narratives; historical thinking - narratives; professional development - primary phase; historical agency

\section{Introduction}

When studying history, students have to deal with interpreting ideas and concepts based on the predominant master narratives that dominate official national discourses, and those transmitted in popular culture and media, or often by family narratives (Barton, 1995). Among other things, these ideas and concepts reflect perspectives on historical agency and historical agents that have important repercussions for students' sense of civic agency/efficacy. This is important when understanding history and the shaping of civic action. As Seixas (2012: 544) points out, understanding historical agency as limited to the action of heroes (or anti-heroes, we should add) is linked to what he defined as a 'historical pedagogy of submission', whereas students recognizing the role played by all citizens and social classes in the past could lead to a better understanding of the importance of collective action that 'enhances their capacities as agents in the present' (Den Heyer, 2003a: 412).

Although historical writing has been gradually transformed in order to understand the role of collective action in historical processes - what Seixas (2012: 543) defined as the 'democratization' of historical agency - the presence of individual narratives in school curricula (Barton and Levstik, 2004) and textbooks (Éthier et al., 2013) is still common and disproportionate. Educational research illuminates how teachers and pre-service teachers often struggle to offer and construct an alternative history to the 'main story' as it moves away from a positive image of the past (Levstik, 2000: 287) and to 'tread into the complex, contentious ground of conflicts among groups' (Doornbos and Halvorsen, 2017: 222). Teachers also tend to focus upon large-scale institutions or abstract entities, or introduce events that explain changes in history, without paying 
attention to the social groups that contributed to those events (Barton, 2017; Den Heyer, 2003a). When these are included, they are generally depicted as victims (Barton, 2012; Doornbos and Halvorsen, 2017; Seixas, 2012). As a result, historical agency is usually left undiscussed in lessons (Barton, 2012).

The presence of iconic renowned or heroic individuals as historical agents is also common in students' own historical narratives, accounts and stories (Barton, 1997; Den Heyer, 2003a; Den Heyer and Fidyk, 2007; Halldén, 2009; Kropman et al., 2015; Lee et al., 1997; Peck et al., 2011; Seixas, 1993, 2012). Students do not enter the classroom free of intellectual baggage and prior knowledge, since they belong to various groups (family, friends and so on) and are surrounded by diverse stimuli (Létourneau, 2006; Wertsch, 1998). Among these is the role played by films, television programmes and the internet in students' perceptions, as they provide clear examples of 'common cultural, gender, or class-specific celebration of individual efficacy' (Den Heyer, 2003a: 418). Unfortunately, as Wineburg et al. (2001: 55) note, 'no algebra or French teacher can compete with such famous history teachers as Steven Spielberg or Oliver Stone', who create images that are engraved in students' minds; these powerful images are difficult for teachers to dismiss. Alongside this, Wills (2005: 110) cites the influence of what he calls the 'politics of memory', related to what slips into the individual and collective memory by way of public memorials, holidays, commemorative activities and vernacular history.

The evidence indicates that students' understanding - that is, historical consciousness - of the past can be simplistic and mistaken. In the specific case of Spain, recent research has shown that students have often assimilated a romanticized vision, which reflects nineteenth-century historiography (Carretero and Van Alphen, 2014; López Rodríguez, 2015; Lopez et al., 2015) and incorporates distorted and sometimes mystifying information, highlighting the role of individuals in history. This information ('fake history') creates intellectual stumbling blocks as students encounter and consider alternative narratives to their preconceptions in their history lessons. Therefore, teachers should audit and consider the 'student's basic matrix of understanding' (Létourneau, 2006: 84) and construct new pedagogic/didactic approaches that develop critical and reflective thinking (Salinas et al., 2012). But what if teachers share this particular vision of the past?

Previous studies of pre-service primary school teachers in Spain showed that they have a view of history embedding stereotypes and misconceptions (Arias Ferrer et al., 2014; Egea Vivancos and Arias Ferrer, 2015; Sáiz Serrano and Gómez Carrasco, 2016) that even textbooks perpetuate (Carretero et al., 2002; Pousa and López Facal, 2013; Sáiz Serrano, 2013; Sánchez et al., 2016). Moreover, the encyclopaedic and conceptual vision of the national education curriculum (López Facal, 2014) still favours a history reflecting the previous master narrative, with a focus on key, iconic, central figures, instead of offering alternative narratives reflecting 'history from below'. And hardly any primary school teachers have experienced an 'alternative history' during their own education (Sáiz Serrano and Fuster García, 2014; Sáiz Serrano and López-Facal, 2015). Therefore, how are teachers going to identify and critique these master narratives, or any other historical narrative? In this sense, Den Heyer and Fidyk (2007: 143) emphasize the need to distinguish between 'history as an account of the past and the actuality of the past'. The simple fact of treating the past as a single narrative (no matter what narrative is being used) ignores the richness and diversity of historical knowledge, which includes discussion of different perspectives, interpretations and agents.

In this study, we focus on the historical knowledge of pre-service primary school teachers, our educators of the future. Primary teachers often provide pupils' first 
experience of the formal study of history. That is why understanding future teachers' conceptions of history is key, given the influence that they have in the educational process (Harnett, 2000; McCrum, 2013; Zumwalt and Craig, 2008). Pre-service teachers also need to understand and be fully aware of the presentation of historical agency, if their future goals are to include teaching critical thinking, or for any meaningful application of historical understanding to students' civic engagement. Also, they need to learn what thinking historically means, that is, understanding history as a process of enquiry with a disciplinary basis of substantive and syntactic conceptual knowledge and the procedures, processes, protocols and skills involved in 'doing history'. Equally important, if teachers are to help students account for agency as a building block of historical interpretation, they need some common understanding of the concept. Without the development of such strategic concepts as agency, the result of historical enquiry would probably tend towards trivial, disconnected and incoherent knowledge (Lee and Ashby, 2000; Lévesque, 2008; VanSledright, 2011, 2014; Wineburg, 2001).

\section{What does historical agency involve?}

Colley (2017: 158) defined historical agency as: 'an individual or groups of individuals in the past (agents) who chose to act (actions) in the context of structures, limitations, and constraints, while facing the intended and/or unintended consequences of their actions'. From this perspective, agency involves intention (Bruner, 1994; Lee et al., 1997; Seixas, 1993, 2012). Intention is often linked to beliefs and desires, the pursuit of specific objectives or the overcoming of obstacles faced by agents (Bruner, 1994; Chapman, 2014). Seixas (2012) further differentiates between reasons for individual actions and desires, and causes, which are conditioned by the context and can be of a voluntary or involuntary nature. A further consideration involves the importance of analysing the consequences of the actions (differentiating between intended or unintended consequences), as well as the category or type of agency (individual, collective, institutional) (Colley, 2017). With regard to this last aspect, Anderson (1980) pointed to three modalities of agency: when actions seek to achieve private objectives, when people are so immersed in a social context that they take part in public objectives or interests, and when actions include a collective objective of social transformation. In this third modality, individual agents work with others and tend to become collective agents with the aim of reaching some of their objectives in a coordinated manner (Callinicos, 2004). This distinction between individual, collective and institutional agency is significant when analysing what is being taught/learned. The narratives of pre-service teachers gathered in this research were analysed using these premises.

\section{Methodology}

The aim of our study was to ascertain student teachers' perceptions of historical agency and the attributes of historical agents in European and Spanish history. We sought to identify which historical agents are most frequently represented in their narratives (Aim 1), to analyse the pattern of actions associated with these agents, and to identify elements that described their perception of the actions developed by those agents (Aim 2). We selected undergraduate students preparing to teach in primary school classrooms because they were most likely to be responsible for pupils' initial experiences of learning about the past, which would shape their future thinking.

To achieve our research objectives, we implemented a narrative exercise aimed at reviewing the previous knowledge of pre-service teachers about history (Egea 
Vivancos et al., 2017). Student groups were assigned a historical period and asked to create a rap account (between four and six verses) of that period. Members of each group decided which historical content to include in the rap, either on the basis of personal interest or on the basis of what they considered the defining moments, events, characteristics and personalities of the period. They were to work from memory, rather than using additional sources. The limited time frame acted as a 'forced choice': students could not include everything of significance from the period, so were forced to make choices about who and what should be included. This proved useful as a reflection of their overall understanding of the main characteristics of each period, including who they considered to be agents of history. As Peck et al. (2011: 258) point out, this type of activity allows researchers to capture the essence of their 'rough and ready' historical knowledge.

The discussion that follows is based on 107 student narratives collected from groups of three to five students each (520 participants in total) during three academic years (2012/13, 2013/14 and 2014/15). Participants ranged in age from 19 to 35 years, with most (about 75 per cent) being between 19 and 20 years old. The vast majority had studied non-compulsory secondary education (the equivalent to high school in the United States and A levels in the United Kingdom) in the fields of social sciences and humanities. We used non-probability convenience sampling. Table 1 shows the number of texts collected related to different periods, those that included agency and the number of agents mentioned.

\section{Table 1: Total number of texts collected by period, indicating those that include} agency and the number of agents that appear

\begin{tabular}{lccc}
\hline & Texts & Texts that include agents & Number of agents \\
\hline Prehistory & 21 & 17 & 17 \\
Ancient history & 18 & 13 & 23 \\
Middle Ages & 38 & 27 & 54 \\
Modern history & 12 & 8 & 19 \\
Late modern history & 18 & 15 & 30 \\
\hline Total & 107 & 80 & 143 \\
\hline
\end{tabular}

The 107 texts collected were given a correlative code number (T001-T107). The compositions were categorized according to the historical periods of a commonly used Mediterranean historical timeline: prehistory, ancient history, Middle Ages, modern period and late modern period (see Table 1). All the lyrics were computerized and sorted by period. A qualitative content analysis was carried out to subdivide them into general categories associated with the topics appearing in the narratives (Creswell, 2012). Concepts were grouped into units (episodes), categories (agent, fact, date and so on) and subcategories according to the properties of the content, drawing on elements such as category, reasons and causes to describe the characteristics of historical agents.

The lecturer assigned the historical period, but the historical episodes, agents and/or events described were freely chosen by the participants. This explains the variety of topics and contents of the texts analysed, since they were a collective product with no right or wrong answer.

In the discussion that follows we focused solely on participants' responses regarding agency. Further, we omitted 27 of the narratives (26 per cent) because they 
contained no elements associated with the concept of agency. Instead, they were centred on descriptions of lifestyles, or listed events and episodes that the participants considered key to the period. Sometimes they employed impersonal verb forms and centred on events rather than on agents as the subjects of their narratives:

The discovery of America was a time of birth; a continent was born, all because of serendipity. (T067)

In some cases, too, a first-person narrator listed a series of actions that, while descriptive, did not identify any intentionality behind the actions:

I would like to travel through Europe with Erasmus. Break free from the church. Throw off its dictates and feel how my spirit of protest grows. (T021)

Similarly, some narratives named historical characters, but failed to mention specific actions, historical causes or ensuing consequences related to human agency: 49 historical figures such as Cleopatra, Charlemagne and Hitler were mentioned as landmarks in a particular historical moment in 65 specific references, but with no more information regarding the actions they developed. They were thus not included in this analysis. As a result, our final sample is based on 143 allusions to historical agents and/ or agency (see Table 1).

Each agent was then classified by category. We distinguish between institutional, collective and individual agents. Institutional agency refers to upper-rank entities, such as the nation (France, Germany and so on) and the church (such as the Catholic Church), or the terminology associated with them, for example 'empire' and 'republic'. In this category we combine what Peck et al. (2011) call nations and corporate bodies. Collective agency refers to human beings as a whole, the people ('we, the people'), to socio-economic groups (slaves, peasants and so on) or the people of a nation as a collective (the French people, the German people and so on). No smaller collective groups (such as political groups or parties, for example) were identified. Finally, historical personalities (for example, Hitler and Mussolini) are associated with individual agency, assumed to be protagonists on account of the actions attributed to them. Nameless or ordinary people are also classified as individual agents, although we found only one example, used when describing prehistory: a farmer (T047).

After establishing the category of agent, we examined patterns of action, where we differentiated between those who perform the action (active agents) and those who receive and suffer from actions (passive subjects). Verbs such as 'defeat', 'conquer', 'devastate', 'advance', 'achieve', 'clamour' and 'complain' are linked to active agency, as the agent or agents lead the action. Verbs such as 'starve', 'defend', 'protect', 'die' and 'succumb' define passive agency. We also described the characteristics of actions, especially those associated with aspects such as reasons and causes.

Once these aspects were established, we recorded the frequency of mention (by historical period and overall) and also those mentions where the name of the agent is avoided and an equivalent is used instead to underline a specific characteristic (for example, using 'the Dictator' instead of 'Franco'), as Wertsch (1998) recommended when analysing historical narratives. 


\section{Findings and discussion}

\section{Historical agents}

A first reading of the results shows that the category that appears most frequently in the students' narratives (Aim 1) is collective agency. It appears 46 per cent of the time (66/143), closely followed by individual agency (37 per cent, or 53/143). References to institutional agency are much less frequent (16 per cent, or 24/143). This initial result should be further explained, as this distribution of representation varies according to the historical period (see Table 2).

Table 2: Number of mentions per historical period and the frequency with which agents appear by category

\begin{tabular}{lcccccc}
\hline & \multicolumn{7}{c}{ Category } \\
\cline { 2 - 7 } & Collective & \multicolumn{1}{c}{ Individual } & Institutional \\
\hline Prehistory & 16 & $(94 \%)$ & 1 & $(6 \%)$ & & \\
Ancient history & 13 & $(57 \%)$ & 8 & $(35 \%)$ & 2 & $(9 \%)$ \\
Middle Ages & 21 & $(39 \%)$ & 22 & $(41 \%)$ & 11 & $(20 \%)$ \\
Modern history & 16 & $(53 \%)$ & 14 & $(74 \%)$ & 5 & $(26 \%)$ \\
Late modern history & 66 & 8 & $(27 \%)$ & 6 & $(20 \%)$ \\
\hline Total & 63 & 53 & 24 & \\
\hline
\end{tabular}

The responses obtained in the narratives about prehistory show a large majority of references in relation to collective agents. The absence of names for influential individuals during this period results in attention being paid to humans acting collectively, with participants identifying such activities as spurring change and producing some form of progress. The herd, the clan or the group are presented as agents that enable the active evolution of the species. In one case, a student invented a fictitious character a farmer - whose individual agency serves to describe the technological advances of that time. In this case, an individual actor serves as a narrative resource to personify what would otherwise be a more generalized and, perhaps, more collective example of agency:

I farm and keep my cattle. At the end, with the writing, I left everything explained. (T047)

Beginning with the period of ancient history and the development of written language and record-keeping, narratives change. Allusions to collectivity are fewer, individual agents surface more often, and some evidence of institutional agency appears. Egypt, Greece and Rome dominate in this period, but participants also mention settler groups from a variety of areas (Greeks, Athenians, Iberians, Hispanics and Romans), or refer to their social role (most often slaves). In regard to Egypt, pharaohs are the only individuals identified with specific actions/agency. Roles rather than names dominate students' narratives about individual agency. Some pharaohs (Cheops, Khafre and Menkaure) or Greek philosophers and intellectuals appear, but they are merely listed and have no action attributed to them that merits their classification under any of the agency categories. We find Helen of Troy, and Xerxes and Leonidas in the context of the GrecoPersian Wars - all figures who students might have encountered in popular media as well as in history classes. A similar situation occurs for Rome. Hispanics, Romans 
and the Empire were the most frequent collective and institutional agents mentioned, while the actions of individual agents were limited to Viriatus and Julius Caesar.

Perhaps not surprisingly, attention to institutional agents, especially the Catholic Church and the institutionalization of the Inquisition, marks students' narratives about the Middle Ages. Collective agents remain frequent, with various references to peasants, servants, craftsmen and other socio-economic groups. Individual agents also populate this period, often associated with the monarchies of the time (Don Rodrigo, Alfonso X, Boabdil, the Catholic Monarchs) or El Cid (as an example of a conqueror), and with Spanish exploration as epitomized by Christopher Columbus, who appears again in the narratives associated with the modern era.

Indeed, Columbus appears frequently as a main agent in narratives about both the periods, and he largely accounts for the high percentage of individual agents mentioned in these narratives. When analysing the narratives regarding the modern era, and based on their tendency to simply list people or episodes, it appears that students' knowledge of this period remains fairly superficial. Their narratives omitted any explanation of the causes and consequences of individual or institutional actions. Agents and actions remain decontextualized, especially in narratives relating to the Catholic Church, the Inquisition, or the complex relations between England, France and Spain. Also noteworthy is the total absence of collective agency for this period.

Finally, in the late modern period, collectivity is more present, particularly in references to the French people (linked to the French Revolution) and Spanish society during the Spanish Civil War, the transition to democracy, the economic crisis, and current issues in Spain or Europe more broadly. In addition, institutions are linked to references to states, especially those related to their participation in armed conflicts. Individual agents are present, but take a secondary role here.

\section{Patterns and main characteristics of the actions}

The types of actions associated with the protagonists mentioned enable us to establish some characteristics and pattern in their actions (Aim 2). We distinguished, for instance, a strictly active agent (one who carried out various actions and affected history, and therefore produced changes) from other protagonists or passive subjects who suffered from or received the action of the agents, and needed to defend and protect themselves (see Table 3). There are fewer instances of reasons or causes/ consequences.

In the narratives focusing on the Palaeolithic era, students described a time when human beings, as a collectivity, discovered fire, developed stone tools and created cave paintings. These descriptions sometimes depicted human intent-people 'strove' to discover fire, for instance - but that striving was unconnected to need, location or the consequences of the action:

Hairy men strove really hard to discover fire. (T092)

The man in the cave did discover the fire. (T073)

An assumption of progress over time in the prehistoric era was accompanied by a focus on how hard life was for humans. Humans must 'struggle' against the environment. But as a collectivity, humans are the leading actors in this struggle: they discovered fire, they created tools with stones, they survived and so on:

Nature vetoes us, survival is our goal. (T044) 


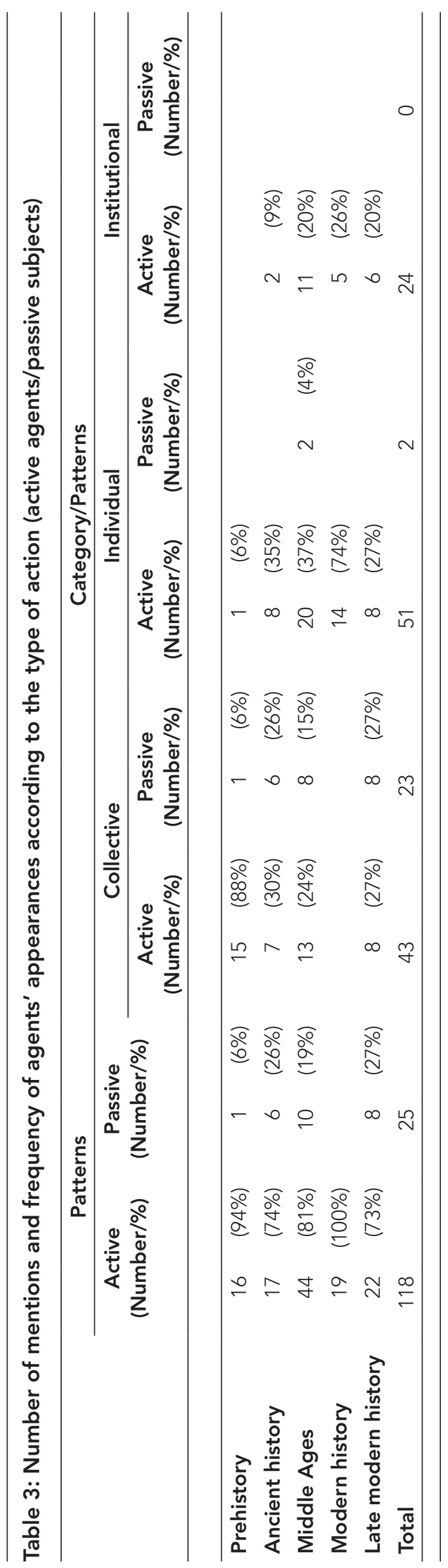


In describing the Neolithic era, some students made explicit references to human beings inventing agriculture and therefore becoming settlers rather than nomads. These instances, the invention of agriculture and development of stoneworking are presented as elements of change leading to settlement, but, as in the previous period, little attention is focused on human intentionality or the involvement of groups or individuals in the results of their actions. In only two instances did students attribute a direct consequence to collective agency:

Manufacturing tools with the stone that you've perfected. Stop being hunters and start to be producers. Get in the seeds as a good farmer should. (T039)

By creating tools, their farming they developed, so the nomads of the world finally were settled. (T073)

Some of the narratives set in prehistoric times addressed the development of metals. However, it was noted that technology had inherent political consequences for people. Students saw the development of metals as leading to wars, but still tended to describe people collectively as passive agents - the beneficiaries of better foodstuffs and the victims of the 'invention' of war. Indeed, in the second transcription below, the metals themselves are seen as 'forging new weapons', leading to wars, and pitting people against each other. In doing so, these student narratives not only stripped humans of choice, they stripped them of responsibility, suggesting inevitability rather than contingency as the primary engine of history:

Each metal is a discovery, its fruits were their foodstuff. It brought despondency among peoples. War was the worst invention. (T042)

Copper, bronze and metal forging new weapons, new wars, people against people. (T048)

Beginning with ancient history students presented two extremes in human collectivity: the oppressors and the oppressed (often masters and enslaved).

In the context of ancient Egypt, students highlighted slaves as characteristic of oppressed, collective, and overwhelmingly passive agents:

Slaves worked like crazy to build pyramids out of nowhere. They were hot and they were sweaty and had no salary to feed them. (T045)

Pharaohs, on the other hand, appeared as individual agents and 'pyramid builders', despite students' recognition that it was the enslaved workforce who actually did the building:

The Egyptian pyramids of Cheops, Khafre and Menkaure, built by the pharaohs but with their neighbours' stones and strength. (TO3)

Students also recalled ancient Greece primarily in terms of protagonists, such as Paris and Agamemnon, or through philosophers such as Aristotle and Plato. Protagonists received some specific attention as historical agents. For example, Helen played a decisive role in the Trojan War:

Between Paris and Agamemnon, Helen took her pick. (T082)

Collectivity appeared in reference to democracy rather than slavery - even though ancient Greece maintained a system of slavery, as Rome and Egypt did. One student 
mentioned the role that Athenians, as a group, had in the creation and fight for democracy as a political system:

\section{Athenians fighting for democracy. (T025)}

In reference to ancient Rome, Romans as collective agents and the Roman Empire as a form of institutional agency predominated - again with no mention of slavery as a feature of collective agency, either regarding those who instituted and maintained that system or from the perspectives of those enslaved. This is an interesting feature of the narratives, and likely an artefact of the ways in which ancient cultures are traditionally introduced as having 'contributed' to modern culture: Egypt with slave-built pyramids that maintained a pharaonic system, Greece offering democracy, and Rome with a lawdriven empire intent on conquest:

To fight as a warrior to conquer the entire world. (T012)

In addition to this allusion to intent, two other narratives included the consequences of expansion and empire, by referring to ancient Rome's legal and architectural impact as 'the cradle of our civilization' that provided a 'great legacy':

The Roman Empire, with its organization, formed the cradle of our civilization. (T078)

The Romans conquered many places ... bequeathing us a great legacy: theatres, circuses and amphitheatres. (T091)

This is particularly interesting in reference to the conquest of the Hispanics and lberians who dominated the Iberian Peninsula prior to Roman occupation. The three narratives referring to the fight against Roman occupation assign intentionality to this action, both in terms of putting an end to Roman oppression and in defending peninsular territory:

In the Iberian Peninsula the Iberians flourished and they always defended their territory. At the end the Romans defeated them. (T038)

Students who produced narratives set in the Middle Ages also assigned agency in terms of conquest (Islamic strongholds on the Iberian Peninsula) and resistance (Christian advances into Muslim territories), in the context of the so-called Reconquista (the Christian expulsion of Muslims from the Iberian Peninsula). In the narrative excerpt below, Hispanics and Christians were assimilated and presented as collective active agents as they were 'taking back their lives':

In the Iberian Peninsula we were at the Reconquista, Hispanics were taking back their lives. (T036)

Similar actions (defence of the land, conquest, advancement and so on) are attributed to territorial bodies such as Aragon and Castille, which are referred to as a collective, or to specific historical figures in Spain, such as Alfonso X, the Catholic Monarchs or El $\mathrm{Cid}$. For this reason, the references to individual agents as active subjects are closely linked with verbs such as 'fight', 'conquer' and 'dominate'.

References to the individual agency of passive subjects are scarce. However, we found two examples from the Middle Ages in the Iberian Peninsula of what literature usually depicted as losers or anti-heroes. First, Roderic, the last Visigoth king, who was defeated by the Muslims in the Battle of Guadalete, was included as a notable figure of the period, even though students note that, as a result of that defeat, Al-Andalus 
flourished. In the second example, Boabdil, the last Muslim ruler, defeated by the Catholic Monarchs in 1492, not only lost an empire, but was symbolically washed by tears:

Roderic defeated, Al-Andalus flourishes. (T054)

Boabdil, you will see your empire fall and woman's tears will run down your face. (T095)

At the institutional level, students also recognized the active agency of the Catholic Church and its Inquisition during this period. In fact, the church was the only active agent to which students assigned intentionality related to ideological control and its consequences:

A bloodthirsty and conscience-depriving Church threatens and terrorizes society. (T061)

The reference to 'society' in this excerpt signalled a second feature of a church/ society dichotomy. The institutional church exercised power over society in the form of servants, peasants and craftsmen, a clear collective who suffered from the absence of agency. They could not alter their place in history, either because of ignorance or because of the rigidity of dominant social and religious institutions. This dichotomy produced the only mentions of historical and social position to explain a collective situation:

Living in social classes with no possibility of ascending. (T033)

If you were born a peasant nothing could ever change it. (T061)

Ignorance ruled the land, obstinately offering its harvests and abundant pleasures to the nobility in order to be to their liking. (T056)

Among the 12 texts alluding to the modern period, there are only 19 references to historical agents. Generally, it seems to be a relatively unknown period for the students, and the narratives provide a simple enumeration of some distinguished characters or specific episodes of history, without further reflection. This lack of knowledge leads towards a complete decontextualization of the actions described. Likewise, the schematic data sequence presented omits any explanation regarding subjects as far as the causes and consequences of their actions are concerned.

Most often, these references focus on the leading figure of Columbus $(n=6)$, who is associated with the action of 'discovering'. Some of the references to this well-known agent involve a total lack of references that would explain the action he performed:

A new way to the East Indies, accidentally finds new lands. A continent is born just by a coincidence. (T023)

Columbus set out on the Ocean and got himself a voyage. (T083)

More commonly, students introduced agents such as Columbus, Galileo, Copernicus, Velázquez and Cervantes in terms of scientific and non-theological cultural spheres. The students recognize their legacy, and some official responses, but do not suggest that there were subsequent effects of their actions:

Galileo discovered that the Earth was moving, then the Inquisition came and said: 'What's that mad man saying?' (T083) 
Interestingly, in this instance, the Inquisition 'came and said' is phrased as if it were a single person rather than an institution representing powerful groups of historical agents. In other cases, students omit individual agents. In the excerpt below, for instance, the printing press appeared (rather than having been invented by someone), and this invention has the power to reinvent culture:

It coincides with the appearance of the printing press and culture gets reinvented. (T041)

Dealing with this period, students most often attributed active historical agency to the Catholic Church, especially in relation to the Inquisition and, sometimes, to states or nations. In the excerpt below, for instance, nations act, the Inquisition arrives, and the bonfire awaits non-Christians, but no human choice is described, no decisions by named individuals - bad things happen, but institutions rather than individuals are responsible. This distancing from human responsibility has important consequences for students as democratic citizens. Citizens are rendered powerless in the face of dehumanized institutions:

They called it New World. England, France and Spain conquered it. A harsh Inquisition arrived in the kingdom, and the bonfire awaited those who were not Christians. (T043)

Just as the early modern period is marked in students' narratives by the rising power of Roman Catholicism, the transition from the modern period to the late modern period is clearly linked to the French Revolution and collective agency - an oppressed people's fight for revolutionary ideals. Rather than individual leaders, students note the French people's agency, or sometimes France's national agency. Further, the French people have a collective intentionality (the defence of freedom), and this ideal of freedom is described as a significant historical stepping stone as 'the people began to think':

When they did not even have bread, France clamoured for freedom. (T070)

The French people sought freedom. They killed the monarchs to achieve equality. They fought together, all as brothers. (T016)

The people began to think, nothing would ever be the same. (T093)

Another feature of the students' narratives is the lack of attention to the entire nineteenth century, so chronologically drawing together the French Revolution, World War I, the Russian Revolution and World War II. In these instances, labouring people appear as collective agents, but chronologies tend to disintegrate. Russian labourers are given no quarter by Hitler and Stalin, with no attention paid in the narratives to the Tsar, peasant uprisings, or the revolutionary period that preceded Stalin's rise in the USSR or Hitler's rise in Germany. Again, humans are not responsible for machines that 'devastate' them, an atom bomb that simply 'appears' and people 'walk like children' to their own destruction. Only the extermination of people in Germany was 'planned', though by the nation, not by specific groups or individuals. Children, Jews or, simply, civilians are shown as the main sufferers of the war, but the perpetrators of war remain invisible. Nations go to war, rather than people electing to do so - or being forced to do so:

Machines came in and they devastated people. (T070)

In Russia labourers complain ... Hitler and Stalin gave no quarter. (T046) 
In Germany an extermination was being planned. (T068)

They walk like defenceless children; an atom bomb appears above. (T010)

In this period, nations take the place of the Catholic Church - omnipresent in the narrations concerning the Middle Ages and the modern period - in terms of institutional agency:

USA, England and France fought against Russia, Germany and Italy in World War II. (T103)

Given that the subjects of this study were Spanish teachers in training, we expected to find mentions of the Spanish Civil War. Not surprisingly, Franco (sometimes simply referred to as 'tyrant' or 'dictator') appears as the primary example of individual agency with 'people' as the collective victims of his agency. He made people starve, constructed an unequal society or condemned people:

In the Peninsula [Spain], General [Franco] made people starve. (T037)

For Spain, as for much of the world, the twentieth century was characterized by war and death. Spain did experience a brief optimistic period during the Spanish transition to a democracy, and for the first years following that transition. Students associated this period with individual agents, such as the first president of the Spanish democracy, Adolfo Suárez, and they also made some brief references to grass-roots movements as examples of collective active agents:

With Adolfo Suárez, Spain began to find stability. (T093)

People took to the streets to shout 'Liberation!' (T007)

In describing contemporary history, students point out the convulsive nature of their own times, but they also note an inability ('the world is organized around a great abyss') or unwillingness (people forget the socio-economic crisis 'when the Soccer World Cup begins') to take action. Overall, people collectively remain observers:

Although we are involved in a socio-economic crisis, the country forgets about it when the Soccer World Cup begins. (T029)

The world is organized around a great abyss. Since its appearance, men succumbed to capitalism. (T107)

In those instances where students did assign intentionality (or its lack), the main aim of the action was always related to the search for freedom and its defence. Thus, Hispanics in their fight against Rome, the French in their opposition to the Ancien Régime, or the Spanish people after the end of Franco's dictatorship, all sought or defended some form of freedom or at least independence. At the same time, the narratives described some of the challenges facing groups if they were to take action on their own behalf. This is the case of slaves or servants, seen as immovably caught in a particular social stratum or, in more recent times, people are seen as attached inexorably to their fate and without a desire to fight for change. Further, references to the context in which action occurs were scarcer. Examples of social context were introduced in order to explain the stagnation of the situation of servants and peasants in the medieval period, but not in other periods. And, finally, students rarely spent much time on the consequences of actions. More often they listed subjects and actions but made few associations between those subjects and actions and any kind of historical consequence. The only explicit attention to connections between past and present 
were vague references to the past having had an influence on the present. They noted that Greek democracy was a precursor of the current political system, that the Roman Empire influenced the lifestyle of the people that were conquered, and that the French Revolution had an influence on succeeding schools of thought, but they provided no evidence for those conclusions.

\section{Conclusions}

In their study of students' understanding of historical agency, Lee et al.'s (1997) research noted that 7-14-year-old British students tended to prioritize individual over collective or institutional agency. At the same time, Barton (1997), detected that 9-11-year-old American students conceptualized history in terms of intention and interaction between specific individuals, overlooking social, economic or political institutions. In our study, collectivity has an important role in adult students'/pre-service teachers' narratives, and these collectives are recognized as active agents to whom an intentionality could be attributed ( 65 per cent, 43/66). But it is also common to find them being presented in a very simple way, as groups suffering because of the power of dominant individuals or institutions (35 per cent, 23/66). This coincides with previous assessments of 16-17-year-old students' narratives in the Canadian context (Peck et al., 2011). Figure 1 shows each category of agency.

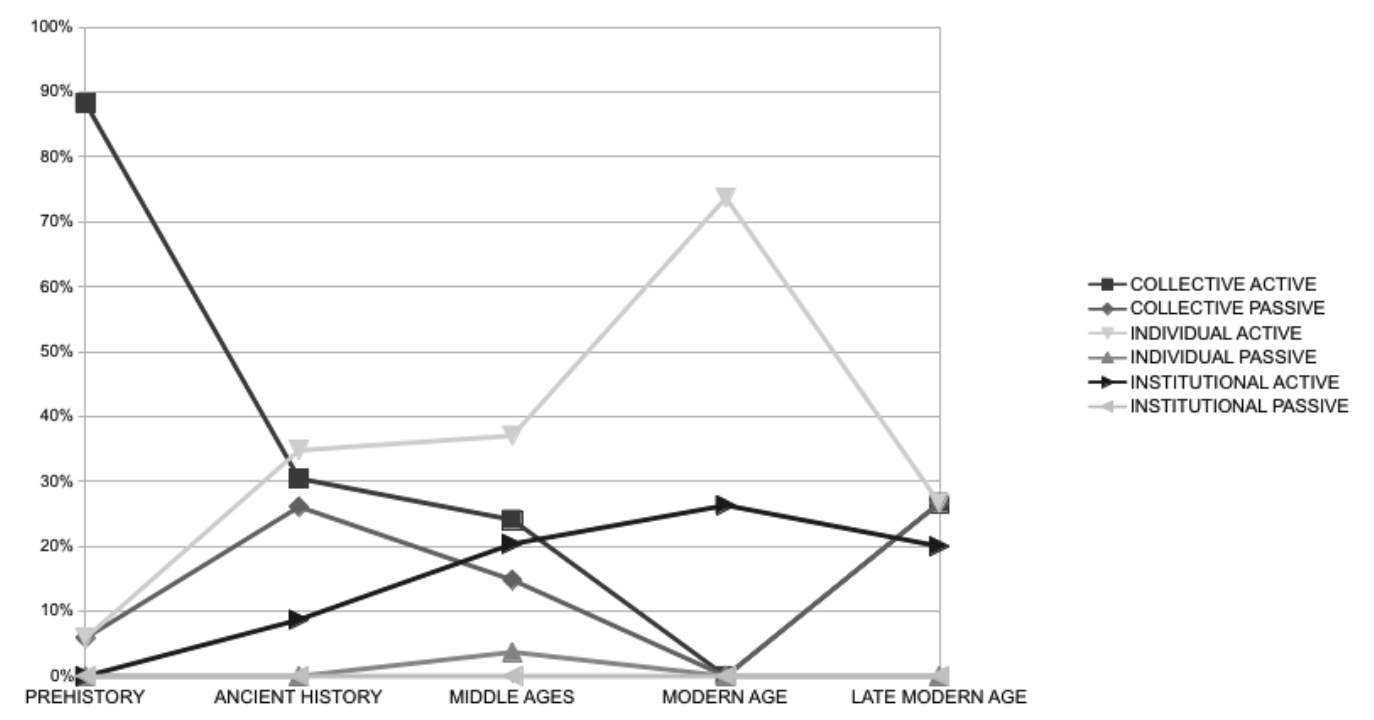

Figure 1: Frequency of each category of agency detected among all those analysed

But, if different periods are compared (see Figure 1), we can see the high frequency of mentions of individual agents, even though collectivity seems to be the majority. In fact, when omitting prehistory data (where collectivity is virtually the only agent mentioned), individual (41 per cent, 52/126) and collective (40 per cent, 50/126) agents have practically the same in frequency of appearance as in the other periods.

The persistent presence of individual agents undoubtedly reflects the weight that these individuals are given in textbooks, in teachers' talks, and in popular culture and media. Individual protagonists and, sometimes, institutional forces act, while collective groups are mostly the recipients of their actions. In the cases analysed, the collectivity does not (or cannot) decide its own fate and has no choice about taking 
action in its own interest. It is unclear whether the participants thought that the lack of choice was due to ignorance or the rigidity of dominant social organizations. That said, collectivity did lead to historical action in very specific cases: when participants could not give specific names for individual agents (for example, during prehistory or even ancient history); when talking about the particular case of the French Revolution - the people rise up and throw off the aristocracy, inventing a new understanding of human rights (Hunt, 2007); or when mentioning specific conflicts that they link with the 'recovery of territory'. In this latter case, collective action is significantly linked with national and master narratives, where traditional historiography has sought to underline the link between certain cultural groups and the idea of a Spanish nation, with very clear oppressor-oppressed, invader-invaded roles. For example, Hispanics and Christians, as collectives, form part of the founding mythology of the Spanish nation, gathered and reinforced by Francoist historiography and still present in the majority of the narratives analysed. This national story is still powerful well beyond the Franco era.

The persistence of these superficial narratives, most frequently simplified in favour of a larger quantity of data (Doornbos and Halvorsen, 2017) and the standardization of knowledge (Den Heyer and Fidyk, 2007), privileges traditional narratives and perpetuates a distorted image of history popularized by television and feature films. These various influences help promote a history based upon individual or institutional achievements, and limit the presence of collective actions and their contribution in the development of history (Barton, 2008). That is why we find it necessary that pre-service teachers (and teachers) become aware of the motivations and intentions of historical agents, and understand the context in which their decisions and actions take place, as well as the repercussions of their deeds. Only by making them understand those aspects will they be able to drive history forward from the conception of historical agents as people with no choice or capacity to act, to recognizing those agents' perceptions and perspectives (Brophy and VanSledright, 1997; Doornbos and Halvorsen, 2017), as well as their influence on historical evolution.

The deficiency discourse of these pre-service students was nevertheless expected based on the body of research already mentioned; what we consider more alarming is their inability to contextualize the facts and knowledge that they have, and to understand that the narrative they favour is only one of the multiple narratives and accounts that recreate the past. Their tendency to reiterate the models trundled out again and again in the textbooks or 'social artefacts' (in the words of Den Heyer and Fidyk, 2007: 146) with no further analysis, ignoring multiple voices, images, perspectives and motivations, results in the frequent introduction in class of 'a familiar story containing a progressively improving plot line populated with iconic leaders to explain change through time' (Den Heyer, 2012: 313). As Bohan and Davis (1998: 175) advised, 'teachers, like historians, must perceive differing perspectives, multiple causation, potential bias in authorship, authenticity of evidence, and view events in context and time period'.

We agree with Wills's conclusion (2005: 128) that 'classrooms should be places for preserving many pasts, for fighting the cultural silencing and collective exclusion that removes people and events from popular memory'. To do that, we should review and reconsider what pre-service teachers really need when approaching their pre-service studies, as they are going to be the educators of the future. We need to commit to a less superficial and more comprehensive and contextualized history teaching, providing pre-service teachers and their pupils - future citizens - with a better understanding of the reasons that have led humankind to the place where it is now. In terms of historical 
agency, reflecting on who makes history ultimately implies thinking about identity, change, society and politics (Den Heyer, 2003b). It is key, then, to give student teachers the necessary pedagogical tools to develop such strategies, if we want to put an end to 'transmissive' and 'factual' teaching practices (Éthier et al., 2013).

\section{Acknowledgements}

This research was supported by the following projects and institutions: Ministerio de Economía y Competitividad, Spain/FEDER (La evaluación de las competencias y el desarrollo de capacidades cognitivas sobre Historia en Educación Secundaria Obligatoria, EDU2015-65621-C3-2-R) and Programa Jiménez de la Espada-Fundación Séneca (19598/EE/14).

\section{Notes on the contributors}

Laura Arias-Ferrer worked for several years as an archaeologist and museum educator. She is currently an associate professor of social studies education at the University of Murcia, Spain. She has published nationally and internationally about teaching history. Her work currently focuses on innovation in teaching practice by introducing archaeology and heritage, the development of historical thinking in early years and on the analysis of prejudices and stereotypes in teaching resources.

Alejandro Egea-Vivancos is an archaeologist and former teacher in secondary education. $\mathrm{He}$ is an associate professor of social studies education at the University of Murcia, Spain. His work currently focuses on innovation in teaching practice by introducing archaeology and heritage and the development of historical thinking in early years and high school. He is editor-in-chief of Panta Rei, a digital research journal focused on both history and teaching history.

\section{References}

Anderson, P. (1980) Arguments within English Marxism. London: Verso.

Arias Ferrer, L., Sánchez lbáñez, R. and Martínez Nieto, A.A. (2014) 'Los estereotipos de la historia en el alumnado universitario'. In Prats, J., Barca, I. and López Facal, R. (eds) Historia e identidades culturales. Braga: CIED-Universidade do Minho, 787-98.

Barton, K.C. (1995) '"My mom taught me": The situated nature of historical understanding'. Paper presented at the American Educational Research Association (AERA) Annual Meeting, San Francisco, 18-22 April 1995. Online. https://files.eric.ed.gov/fulltext/ED387404.pdf (accessed 6 July 2019).

Barton, K.C. (1997) '"Bossed around by the queen": Elementary students' understanding of individuals and institutions in history'. Journal of Curriculum and Supervision, 12 (4), 290-314.

Barton, K.C. (2008) 'A sociocultural perspective on children's understanding of historical change: Comparative findings from Northern Ireland and the United States'. In Levstik, L.S. and Barton, K.C. Researching History Education: Theory, method, and context. New York: Routledge, 300-32.

Barton, K.C. (2012) 'Agency, choice and historical action: How history teaching can help students think about democratic decision making'. Citizenship Teaching and Learning, 7 (2), 131-42.

Barton, K. (2017) 'Overcoming obstacles to teaching about agency'. SO-didaktik, 3, 16-23.

Barton, K.C. and Levstik, L.S. (2004) Teaching History for the Common Good. Mahwah, NJ: Lawrence Erlbaum Associates.

Bohan, C.H. and Davis, O.L. (1998) 'Historical constructions: How social studies student teachers' historical thinking is reflected in their writing of history'. Theory and Research in Social Education, 26 (2), 173-97.

Brophy, J. and VanSledright, B. (1997) Teaching and Learning History in Elementary Schools. New York: Teachers College Press.

Bruner, J.S. (1994) Acts of Meaning. Cambridge, MA: Harvard University Press. 
Callinicos, A. (2004) Making History: Agency, structure, and change in social theory. 2nd ed. Leiden: Brill.

Carretero, M., Jacott, L. and López-Manjón, A. (2002) 'Learning history through textbooks: Are Mexican and Spanish students taught the same story?'. Learning and Instruction, 12 (6), 651-65.

Carretero, M. and Van Alphen, F. (2014) 'Do master narratives change among high school students? A characterization of how national history is represented'. Cognition and Instruction, 32 (3), 290-312.

Chapman, A. (2014) 'The "Good old cause"? Developing children's understandings of historical explanation'. In Schmidt, M.A., Barca, I. and Urban, C. (eds) Passados Possíveis: A Educaçao Histórica em Debate. ljuí: Unijuí, 71-86.

Colley, L. (2017) 'Judging on their looks: Understanding pre-service social studies teachers' conceptions of historical agency and gender'. Journal of Social Studies Research, 41 (2), 155-66.

Creswell, J.W. (2012) Educational Research: Planning, conducting, and evaluating quantitative and qualitative research. 4th ed. Boston: Pearson.

Den Heyer, K. (2003a) 'Between every "now" and "then": A role for the study of historical agency in history and citizenship education'. Theory and Research in Social Education, 31 (4), 411-34.

Den Heyer, K. (2003b) 'Historical agency and social change: Something more than "symbolic" empowerment'. In Allen, L., Breault, D., Cartner, D., Setser, B., Hayes, M., GaztambideFernandez, R. and Krasny, K. (eds) Curriculum and Pedagogy for Peace and Sustainability. Troy, NY: Educator's International Press, 39-58.

Den Heyer, K. (2012) 'Mapping the shadow: Bringing scholarship and teachers together to explore agency's shape and content in social change'. Theory and Research in Social Education, 40 (3), 292-323.

Den Heyer, K. and Fidyk, A. (2007) 'Configuring historical facts through historical fiction: Agency, art-in-fact, and imagination as stepping stones between then and now'. Educational Theory, 57 (2), 141-57.

Doornbos, L. and Halvorsen, A.-L. (2017) 'Agency and historical inquiry in the elementary classroom'. In Andrews, G.P. and Wangdi, Y.D. (eds) The Role of Agency and Memory in Historical Understanding: Revolution, reform, and rebellion. Newcastle upon Tyne: Cambridge Scholars Publishing, 221-46.

Egea Vivancos, A. and Arias Ferrer, L. (2015) 'Russell Crowe el gladiador, Colón el descubridor y otros protagonistas de la Historia: Buceando en las narrativas históricas de jóvenes universitarios españoles'. Clío: History and History Teaching, 41, 1-28. Online. http://clio.rediris.es/n41/ articulos/Egeaarias2015.pdf (accessed 6 July 2019).

Egea Vivancos, A., Arias Ferrer, L. and Clares Clares, M.E. (2017) 'Historia a ritmo de rap: Una propuesta interdisciplinar para la enseñanza de las Ciencias Sociales y la Educación Artística'. Espiral: Cuadernos del profesorado, 10 (20), 51-7. Online. https://tinyurl.com/y3hbebgm (accessed 6 July 2019).

Éthier, M.-A., Lefrançois, D. and Demers, S. (2013) 'An analysis of historical agency in Québec history textbooks'. Education, Citizenship and Social Justice, 8 (2), 119-33.

Halldén, O. (2009) 'On the paradox of understanding history in an educational setting'. In Leinhardt, G., Beck, I.L. and Stainton, C. (eds) Teaching and Learning in History. New York: Routledge, 27-46.

Harnett, P. (2000) 'History in the primary school: Re-shaping our pasts: The influence of primary school teachers' knowledge and understanding of history on curriculum planning and implementation'. International Journal of Historical Learning, Teaching and Research, 1 (1), 1-14.

Hunt, L. (2007) Inventing Human Rights: A history. New York: W.W. Norton and Company.

Kropman, M., Van Boxtel, C. and Van Drie, J. (2015) 'Small country, great ambitions: Prospective teachers' narratives and knowledge about Dutch history'. In Chapman, A. and Wilschut, A. (eds) Joined-Up History: New directions in history education research. Charlotte, NC: Information Age Publishing, 57-84.

Lee, P. and Ashby, R. (2000) 'Progression in historical understanding among students ages 7-14'. In Stearns, P.N., Seixas, P. and Wineburg, S. (eds) Knowing, Teaching, and Learning History: National and international perspectives. New York: New York University Press, 199-222.

Lee, P., Dickinson, A. and Ashby, R. (1997) '"Just another emperor": Understanding action in the past'. International Journal of Educational Research, 27 (3), 233-44.

Létourneau, J. (2006) 'Remembering our past: An examination of the historical memory of young Québécois'. In Sandwell, R.W. (ed.) To the Past: History education, public memory, and citizenship in Canada. Toronto: University of Toronto Press, 70-87.

Lévesque, S. (2008) Thinking Historically: Educating students for the twenty-first century. Toronto: University of Toronto Press. 
Levstik, L.S. (2000) 'Articulating the silences: Teachers' and adolescents' conceptions of historical significance'. In Stearns, P.N., Seixas, P. and Wineburg, S. (eds) Knowing, Teaching, and Learning History: National and international perspectives. New York: New York University Press, 284-305.

Lopez, C., Carretero, M. and Rodriguez-Moneo, M. (2015) 'Conquest or reconquest? Students' conceptions of nation embedded in a historical narrative'. Journal of the Learning Sciences, 24 (2), 252-85.

López Facal, R. (2014) 'La LOMCE y la competencia histórica'. Ayer, 94 (2), 273-85.

López Rodríguez, C. (2015) 'Repensando las narrativas nacionales: Un análisis del origen, transmisión e influencia en el aprendizaje histórico'. Panta Rei: Revista digital de Ciencia y Didáctica de la Historia, 77-92.

McCrum, E. (2013) 'History teachers' thinking about the nature of their subject'. Teaching and Teacher Education, 35, 73-80.

Peck, C., Poyntz, S. and Seixas, P. (2011) '“'Agency" in students' narratives of Canadian history'. In Perikleous, L. and Shemilt, D. (eds) The Future of the Past: Why history education matters. Nicosia: Association for Historical Dialogue and Research, 253-80.

Pousa, M. and López Facal, R. (2013) 'Eurocentric history in Spanish textbooks'. International Journal of Historical Learning, Teaching and Research, 12 (1), 107-20.

Sáiz Serrano, J. (2013) 'Alfabetización histórica y competencias básicas en libros de texto de historia y en aprendizajes de estudiantes'. Didáctica de las Ciencias Experimentales y Sociales, 27, 43-66.

Sáiz Serrano, J. and Fuster García, C. (2014) 'Memorizar historia sin aprender pensamiento histórico: Las PAU de Historia de España'. Investigación en la Escuela, 84, 47-57.

Sáiz Serrano, J. and Gómez Carrasco, C.J. (2016) 'Investigar el pensamiento histórico y narrativo en la formación del profesorado: Fundamentos teóricos y metodológicos'. Revista Electrónica Interuniversitaria de Formación del Profesorado, 19 (1), 175-90.

Sáiz Serrano, J. and López-Facal, R. (2015) 'Competencias y narrativas históricas: El pensamiento histórico de estudiantes y futuros profesores españoles de educación secundaria'. Revista de Estudios Sociales, 52, 87-101.

Salinas, C., Blevins, B. and Sullivan, C.C. (2012) 'Critical historical thinking: When official narratives collide with other narratives'. Multicultural Perspectives, 14 (1), 18-27.

Sánchez, R., Arias, L. and Egea, A. (2016) 'The perduration of master narratives: The "discovery", conquest and colonisation of America in Spanish history textbooks'. International Journal of Historical Learning, Teaching and Research, 13 (2), 127-37.

Seixas, P. (1993) 'Historical understanding among adolescents in a multicultural setting'. Curriculum Inquiry, 23 (3), 301-27.

Seixas, P. (2012) 'Historical agency as a problem for researchers in history education'. Antíteses, 5 (10), 537-53.

VanSledright, B.A. (2011) The Challenge of Rethinking History Education: On practices, theories, and policy. New York: Routledge.

VanSledright, B.A. (2014) Assessing Historical Thinking and Understanding: Innovative designs for new standards. New York: Routledge.

Wertsch, J.V. (1998) Mind as Action. New York: Oxford University Press.

Wills, J.S. (2005) '“Some people even died": Martin Luther King, Jr, the civil rights movement and the politics of remembrance in elementary classrooms'. International Journal of Qualitative Studies in Education, 18 (1), 109-31.

Wineburg, S. (2001) Historical Thinking and Other Unnatural Acts: Charting the future of teaching the past. Philadelphia: Temple University Press.

Wineburg, S., Mosborg, S. and Porat, D. (2001) 'What can Forrest Gump tell us about students' historical understanding?'. Social Education, 65 (1), 55-8.

Zumwalt, K. and Craig, E. (2008) 'Who is teaching? Does it matter?'. In Cochran-Smith, M., FeimanNemser, S., Mclntyre, D.J. and Demers, K.E. (eds) Handbook of Research on Teacher Education: Enduring questions in changing contexts. 3rd ed. New York: Routledge, 404-23. 
